\title{
Two patients with premature labour associated with Mycoplasma hominis infection
}

\author{
M. SHIMADA, T. KOTANI, H. SAMESHIMA*, Y. NAGAMINE*, Y. KODAMA*, T. IKENOUE*, \\ T. KENRI†, T. SASAKI† and S. OHTAKI
}

Central Laboratory for Clinical Investigation and * Department of Obstetrics and Gynecology, Miyazaki Medical College Hospital, Kihara 5,200, Kiyotake, Miyazaki 889-16 and †Department of Safety Research on Biologics, National Institute of Health, Gakuen 4-7-1, Musashimurayama, Tokyo 208, Japan

\begin{abstract}
Because several reports have suggested that bacterial vaginosis causes premature labour and early rupture of the fetal membranes, the presence of a bacterial flora that causes bacterial vaginosis is thought to be a risk factor for premature labour. The present study investigated two patients with premature delivery and intra-uterine Mycoplasma hominis infection. In microbiological studies, Gram's staining of amniotic fluids revealed numerous neutrophils and epithelial cells but no micro-organisms. Culture of amniotic fluid before antibiotic therapy yielded only $M$. hominis under anaerobic conditions; aerobic culture was negative. Vaginal discharge taken on the day of delivery yielded no growth in case 1 and $M$. hominis and Enterococcus faecalis in case 2. Maternal sera showed specific antibodies to $M$. hominis by ELISA and immunoblotting. As no possible cause of premature labour other than $M$. hominis infection was detected, it is concluded that the intra-uterine $M$. hominis infection was associated with premature labour in these patients.
\end{abstract}

\section{Introduction}

Mycoplasma hominis is isolated frequently from the human genital tract. It has been suggested that $M$. hominis can cause pelvic inflammatory disease [1], sepsis, wound infection, etc. [2]. Recent reports have suggested that women with bacterial vaginosis and vaginal gram-negative anaerobes and $M$. hominis are at the highest risk for the premature delivery of low birth weight infants [3]. This study describes two cases in which $M$. hominis infection was thought to cause premature labour. The clinical courses and laboratory findings in these cases are reported.

\section{Patients and methods}

Case 1

A 26-year-old woman was admitted to this hospital on 20 Aug. 1992 because of premature labour due to intrauterine infection. This was her first planned pregnancy and gestation was 26 weeks. The body

Received 4 March 1997; revised version accepted 10 June 1997.

Corresponding author: Dr S. Ohtaki. temperature was $38^{\circ} \mathrm{C}$, leucocyte count was $24000 / \mu 1$ and $\mathrm{C}$-reactive protein was $4 \mathrm{mg} / \mathrm{dl}$. She delivered the baby several hours after admission. The baby exhibited no signs of clinical illness. Apgar scores at 1 and $5 \mathrm{~min}$ were 8 and 9 , respectively. After delivery she was given $2 \mathrm{~g}$ of cefotiam per day for 4 days. Although cefotiam decreased her body temperature to $37^{\circ} \mathrm{C}$, C-reactive protein of $3.5 \mathrm{mg} / \mathrm{dl}$ persisted. Culture of the white and slightly turbid amniotic fluid yielded $M$. hominis, but there was no growth of bacteria from vaginal discharge. Gram-staining of the amniotic fluid and vaginal discharge showed only white blood cells. Histological examination of placental sections with both haematoxylin and eosin and methylene blue staining revealed neutrophilic infiltration in the chorioamniotic plates and around the umbilical vein, but did not show bacteria.

\section{Case 2}

A 25-year-old woman with premature membrane rupture and suspicion of intra-uterine infection was admitted to this hospital on 16 April 1994. Gestation was 32 weeks. Her obstetric history was as follows: dilatation and curettage at 18 years, spontaneous abortion at 13 weeks of pregnancy at 22 years, and at 23 years a Caesarean section at 40 weeks of 
pregnancy for fetal distress. On admission, leucocyte count was $15000 / \mu \mathrm{l}$, C-reactive protein $2 \mathrm{mg} / \mathrm{dl}$ and body temperature $37.1^{\circ} \mathrm{C}$. Four days after admission, a Caesarean section was performed at 32 weeks gestation for progressive fetal distress. Apgar scores at 1 and 5 min were 7 and 10 , respectively. The baby showed no signs of clinical illness. Maternal leucocyte count and C-reactive protein after operation increased to $16700 / \mu \mathrm{l}$ and $14.3 \mathrm{mg} / \mathrm{dl}$, respectively. Cefotiam at $600 \mathrm{mg} /$ day for 3 days was administered as empirical therapy. Culture of the amniotic fluids yielded $M$. hominis. Culture of vaginal discharge and cervical secretions obtained at Caesarean section yielded $M$. hominis and Enterococcus faecalis. Light microscopic examination showed many white blood cells and epithelial cells. On histological examination, similar findings to those in case 1 were observed.

\section{Patients' sera}

Acute phase serum was taken from the maternal blood when $M$. hominis was isolated. Convalescent serum was collected 7 weeks after isolation of $M$. hominis in case 1 , and 3 weeks after isolation in case 2 . All sera were kept at $-70^{\circ} \mathrm{C}$ until testing.

\section{Isolation and identification of M. hominis}

Amniotic fluids and cervicovaginal secretions were streaked on modified Gifu Anaerobic Medium (GAM) blood agar (Nissui Pharmaceutical Co. Ltd, Tokyo, Japan) for isolation of anaerobic bacteria, chocolate agar (Nissui Pharmaceutical Co. Ltd) for isolation of Gardnerella vaginalis and Neisseria gonorrhoeae, Trypticase Soy Agar II with sheep blood 5\% (Nippon Becton Dickinson Co. Ltd, Tokyo, Japan) and BTB Lactose Agar (Eiken Chemical Co. Ltd, Tokyo, Japan) for isolation of aerobic bacteria, respectively. Modified GAM blood agar was incubated under anaerobic conditions $\left(\mathrm{N}_{2} \quad 80 \%, \mathrm{H}_{2} 10 \%, \mathrm{CO}_{2} 10 \%\right)$ for 7 days and chocolate agar in air with $\mathrm{CO}_{2} 5 \%$ for 5 days. Both trypticase soy agar II with sheep blood 5\% and BTB lactose agar were incubated in aerobic conditions for $72 \mathrm{~h}$. M. hominis was identified by the metabolic inhibition (MI) test [4] with specific rabbit antisera against $M$. hominis, $M$. orale and $M$. salivarium, respectively.

\section{Micro-organisms and growth conditions}

M. hominis $\mathrm{PG} \angle 1$ was grown at $37^{\circ} \mathrm{C}$ in a broth medium consisting of PPLO Broth Base (Difco Laboratories, Detroit, MI, USA) $2.1 \% \mathrm{w} / \mathrm{v}$, phenol red $0.01 \% \mathrm{w} / \mathrm{v}$, and arginine monohydrochloride $0.25 \% \mathrm{w} / \mathrm{v}$. The cells grown in $1 \mathrm{~L}$ of culture medium were centrifuged ( $16000 \mathrm{~g}$ for $30 \mathrm{~min}$ ) when the $\mathrm{pH}$ of the medium began to change. The pellets were washed twice by centrifugation and resuspended in $5 \mathrm{ml}$ of PBS. The cell suspension was sonicated at $20000 \mathrm{~Hz}$ for $3 \mathrm{~min}$ and used as the cell lysate.
Measurement of antibodies against M. hominis, Chlamydia trachomatis and Ureaplasma urealyticum

Antibodies to $M$. hominis were measured by enzymelinked immunosorbent assay (ELISA) and the MI test. The ELISA was performed according to the procedures described by Sasaki et al. [5, 6]. An ELISA value of $>0.15$ was regarded as positive for $M$. hominis infection in the light of values from normal sera in this ELISA system. Antibody titres for $U$. urealyticum and $C$. trachomatis were assayed by the MI test and microimmunofluorescence technique, respectively.

\section{Immunoblotting}

Immunoblotting was performed according to the procedures described by Sasaki et al. [6].

\section{Estimation of protein concentration}

Protein concentrations were determined by the method of Lowry et al. [7] with bovine serum albumin as a standard.

\section{Results}

After incubation for $72 \mathrm{~h}$, only modified GAM blood agar yielded microcolonies which glistened and were translucent in both cases. In the MI test, only anti- $M$. hominis serum inhibited the growth of the isolated micro-organisms. The above results showed that the micro-organisms from specimens of the patients were $M$. hominis. Acute phase and convalescent sera showed 0.025 and 0.410 ELISA values at $\mathrm{A}_{405 \mathrm{~nm}}$, respectively, in case 1 . Similarly, in case 2, 0.489 and 0.772 ELISA values were obtained in paired sera. In further analysis by immunoblotting, convalescent sera from both cases showed some reactive bands that were not recognised in acute phase sera (Fig. 1). Maternal MI antibody titre to 14 serotypes of $U$. urealyticum were all $<20$. IgM antibody titre to $C$. trachomatis was also $<10$.

\section{Discussion}

There have been several reports suggesting that bacterial vaginosis influences the outcome of pregnancy in association with premature labour and premature rupture of the membranes. In a cohort study, Hillier et al. demonstrated that women with bacterial vaginosis and infection with Bacteroides spp. and $M$. hominis were at the highest risk of premature delivery of low birth weight infants [3], because bacterial vaginosis appears to predispose to an ascending infection of the chorioamnion and amniotic fluid and this subsequently leads to prematurity $[3,8]$.

As preterm infection of the chorioamnion appears to have many bacterial causes, it is difficult to assess the 


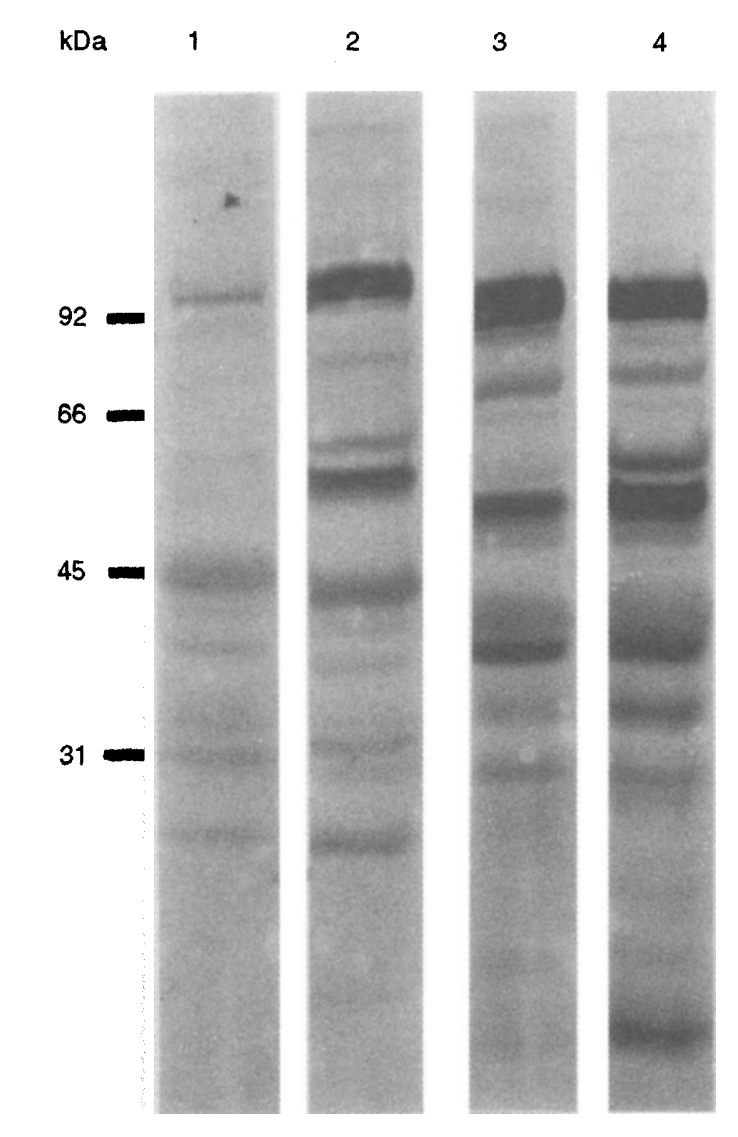

Fig. 1. Immunoblotting analysis of paired sera. Convalescent sera recognise different $M$. hominis proteins from acute phase sera. Lane 1, acute phase serum from patient $1 ; 2$, convalescent serum from patient $1 ; 3$, acute phase serum from patient $2 ; 4$, convalescent serum from patient 2 .

role of any single organism in chorioamnionitis and prematurity [9]. However, we have encountered rare cases of preterm delivery with intra-uterine $M$. hominis infection. Only a few case reports on abortion due to $M$. hominis infection in the upper genitourinary tract have been described in the past [10-12]. Nevertheless, these patients had additional risk factors for spontaneous abortion. A rise in antibody titre against $M$. hominis was not recognised $[10,11]$ and the presence of another micro-organism which might have been the actual aetiological agent was not completely excluded $[10,12]$. In the present cases, only $M$. hominis was isolated from their amniotic fluids collected by intra-abdominal amniocentesis before antibiotic administration, although the study did not attempt to isolate bacteria from chorion and amnion. Furthermore, the results of immunoblotting and ELISA corroborated $M$. hominis infection. As it has been reported that vaginal colonisation by lactobacilli in pregnant women appeared to protect against premature delivery [13], we considered that absence of vaginal lactobacillus contributed to an ascending intra-uterine infection by $M$. hominis. In case 2, acute phase serum showed a positive ELISA value for $M$. hominis infection. This result was thought to be due to the patient having chronic $M$. hominis infection before admission. Thus, it was speculated that intra-uterine $M$. hominis infection caused the premature labour in these two patients.

In a prospective study of the vaginal flora, $G$. vaginalis, $U$. urealyticum and $M$. hominis commonly persisted between midtrimester and labour, particularly in the preterm cohort. However, these organisms were rarely acquired late in pregnancy [14]. Furthermore, bacterial vaginosis is associated with an increased rate of second trimester miscarriage and premature delivery. These findings suggest that any treatment aimed at the eradication of these micro-organisms in pregnancy should not be given later than the beginning of the second trimester of pregnancy [15]. Metronidazole is effective but toxic, and it is not recommended for use in pregnant women. Because of efficacy and safety considerations, clindamycin (CLDM) is preferred to metronidazole for bacterial vaginosis [16]. However, McGregor et al. reported that local administration of CLDM to pregnant women with bacterial vaginosis was ineffective in reducing the incidence of premature labour, even though clinical efficacy was observed. Because local administration is hardly effective against bacteria which have invaded the uterus, they suggested systemic administration of CLDM [17]. Further study on the treatment of $M$. hominis infection is eagerly awaited.

\section{References}

1. Taylor-Robinson D, McCormack WM. The genital mycoplasmas (Part 2). N Engl J Med 1980; 302: 1063-1067.

2. Madoff S, Hooper DC. Nongenitourinary infections caused by Mycoplasma hominis in adults. Rev Infect Dis 1988; 10: 602613.

3. Hillier SL, Nugent RP, Eschenbach DA et al. Association between bacterial vaginosis and preterm delivery of a lowbirth-weight infant. $N$ Engl $J$ Med 1995; 333: 1737-1742.

4. Taylor-Robinson D, Purcell RH, Wong DC, Chanock RM. A colour test for the measurement of antibody to certain mycoplasma species based upon the inhibition of acid production. J Hyg 1966; 64: 91-104.

5. Sasaki T, Bonissol C, Stoiljkovic B. Cross-reactive antibodies to mycoplasmas found in human sera by the enzyme-linked immunosorbent assay (ELISA). Microbiol Immunol 1987; 31: $521-530$.

6. Sasaki T, Bonissol C, Stoiljkovic B, Ito K. Demonstration of cross-reactive antibodies to mycoplasmas found in human sera by ELISA and immunoblotting. Microbiol Immunol 1987; 31: 639-648.

7. Lowry $\mathrm{OH}$, Rosebrough NJ, Farr AL, Randall RJ. Protein Measurement with the folin phenol reagent. J Biol Chem 1951; 193: $265-275$.

8. Holst E, Goffeng AR, Andersch B. Bacterial vaginosis and vaginal microorganisms in idiopathic premature labor and association with pregnancy outcome. J Clin Microbiol 1994; 32: $176-186$

9. Hillier SL, Martius J, Krohn M, Kiviat N, Holmes KK, Eschenbach DA. A case-control study of chorioamnionic infection and histologic chorioamnionitis in prematurity. $N$ Engl J Med 1988; 319: 972-978.

10. Brunell PA, Dische RM, Walker MB. Mycoplasma, amnionitis, and respiratory distress syndrome. JAMA 1969; 207: 20972099.

11. Harwick HJ, Iuppa JB, Fekety FR. Microorganisms and amniotic fluid. Obstet Gynecol 1969; 33: 256-259. 
12. Christensen KK, Hägerstrand I, Mårdh P-A. Late spontaneous abortion associated with Mycoplasma hominis infection of the fetus. Scand J Infect Dis 1982; 14: 73-74.

13. Krohn MA, Hillier SL, Nugent RP et al. The genital flora of women with intraamniotic infection. $J$ Infect Dis 1995; 171: 1475-1480.

14. McDonald HM, O'Loughlin JA, Jolley PT, Vigneswaran R, McDonald PJ. Changes in vaginal flora during pregnancy and association with preterm birth. $J$ Infect Dis 1994; 170: $724-728$.
15. Hay PE, Morgan DJ, Ison CA et al. A longitudinal study of bacterial vaginosis during pregnancy. Br J Obstet Gynaecol 1994; 101: 1048-1053.

16. Greaves WL, Chungafung J, Morris B, Haile A, Townsend JL. Clindamycin versus metronidazole in the treatment of bacterial vaginosis. Obstet Gynecol 1988; 72: 799-802.

17. McGregor JA, French JI, Jones W et al. Bacterial vaginosis is associated with prematurity and vaginal fluid mucinase and sialidase: results of a controlled trial of topical clindamycin cream. Am J Obstet Gynecol 1994; 170: 1048-1060. 